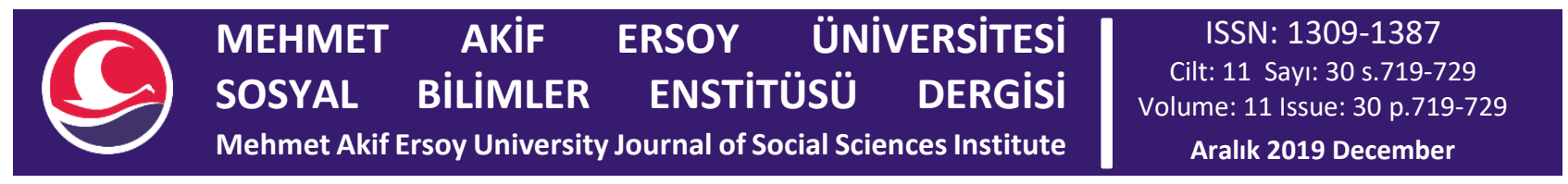

\title{
6360 SAYILI KANUN SONRASI KIR-KENT AYRIMI BAKIMINDAN JANDARMANIN GÖREV VE SORUMLULUKLARININ DEĞERLENDİIILMESİ*
}

\section{EVALUATION OF THE DUTIES AND RESPONSIBILITIES OF THE GENDARMERIE IN TERMS OF RURAL-URBAN SEPARATION AFTER THE LAW 6360}

\author{
Ahmet UÇAR ${ }^{1}$, Rasim AKPINAR ${ }^{2}$, İsmail BAŞARAN ${ }^{3}$
}

1. Doç. Dr., Manisa Celal Bayar Üniversitesi, İ̈BF, Uluslararası İlişkiler Bölümü, ahmet.ucar@cbu.edu.tr,

https://orcid.org/0000-0002-2533-7887

2. Doç. Dr., Manisa Celal Bayar Üniversitesi, İIBF, Kamu Yönetimi Bölümü, rasim.akpinar@cbu.edu.tr, https://orcid.org/0000-0003-1834-6993

3. Dr. Öğr. Üyesi, Manisa Celal Bayar Üniversitesi, İ̇B, Kamu Yönetimi Bölümü,

ismail.basaran@cbu.edu.tr,

https://orcid.org/0000-0002-2533-7887

Makale Türü

Araştırma Makalesi

Başvuru Tarihi

23.09.2019

Yayına Kabul Tarihi 22.11.2019

Article Type
Research Article

pplication Date
09.23 .2019

Admission Date
11.22 .2019

DOI

10.20875/makusobed.623444

* Bu makale Kaysem 13 18-20 Nisan Gaziantep'te sunulmuş olan bildirinin genişletilmiş halidir.
$\ddot{\mathbf{O z}}$

6 Aralık 2012 tarihinde "6360 sayılı On Üç Büyükşehir Belediyesi ve 26 İlçe Kurulması ile Bazı Kanun ve Kanun Hükmünde Kararnamelerde Değişiklik Yapılmasına Dair Kanun” çıkarılmıștır. 6360 sayılı Yasa ile Türk Yerel Yönetim Sistemine yeni bir yönetim sistematiği getirilerek il mülki sınırlarında hizmet üretecek, büyükșehir belediye modeli benimsenmiștir. Bu yasa ile büyükşehir belediye tanımında değişikliğe gidilerek orta büyüklükteki kentler de "Büyükşsehir Belediyesi” statüsü kazanmıştır. Yasa ile 13 ilde büyükşehir belediyesi kurulmuştur. 6360 sayılı Yasa ile, daha önce 5216 sayılı Yasa ile getirilen ve İstanbul ile Kocaeli için geçerli olan, belediye sınırlarının mülki idari sınırlarıyla aynı olması uygulaması tüm büyükş̧ehir belediyeleri için geçerli hale gelmiștir. Böylelikle büyükșehirlerde kır-kent ayırımı hizmet verme alanı bakımından ortadan kalkmış; büyükşehir belediyelerinin hizmet alanı tüm mülki il alanı olmuştur. Bu minvalde, çalışmanın temel amacı 6360 sayılı Kanunun illerde iç güvenlik hizmeti ve örgütlenmesi konusunu, 6638 sayılı Kanun çerçevesinde yetki ve sorumluluk paylaşımı, merkezileşme-yerelleşme, merkezi idare-yerel yönetimler ilişkileri bağlamında bütüncül olarak ele almak olacaktır. 6360 sayılı Kanunla ortaya çıkan hukuki ve idari boşluğu kapatmak maksadıyla 2015 yılının mart ayında 6638 sayılı Kanun ile bir düzenleme yapıldığı bilinmektedir. Jandarma teşkilatııın buna benzer biçimde kır-kent ayırımı bakımından büyükşehirlerdeki konumu bu çalışmanın temel sorunsalı olacaktır.

Anahtar Kelimeler: 6360 Sayılı Kanun, Metropol, Kırsal Alan, Kent, Jandarma,

Abstract

Districts and Amendments in Certain Laws and Decree Laws" was enacted. With the Law 6360, a new management system has been included in the Turkish Local Management System, and the metropolitan municipality model providing services in provincial territorial borders has been adopted. Whit this law, changing the definition of metropolitan municipality, medium-sized cities have also gained "Metropolitan Municipality" status. Whit the law, 13 new metropolitan municipalities were established in 13 provinces. The implementation of provincial territorial borders on the municipal services adopted for İstanbul and Kocaeli Metropolitan Municipalities with former law 5216 has become effective for all metropolitan municipalities with the law 6360 . Thus, in terms of services there are no differences between rural and urban in metropolitan municipalities and service area of metropolitan municipalities has become provincial territorial borders. In this sense, this study mainly aims to analyze the topic of inner security services and organization in the law 6360 comparing with the law 6638 in the point of sharing competence and responsibility, centralization-localization, relations between central and local governments in detail. It is known that a regulation with the law 6638 was made in 2015 to fill the legal and administrative gap come out by the law 6360 . The main problem of this study will be the status of organization of gendarmerie in metropolitan municipalities in terms of rural-urban separation for its responsibilities.

Keywords: The Law 6360, Metropolitan, Rural Area, City, Gendarmerie, 


\section{GíRiş}

Bilindiği gibi 21.yüz yıl Dünya'da küreselleşmenin hız kazandığı ve buna bağlı olarak dünyadaki devletlerin yönetim yapılarında da bir takım değişikliklerin olduğu görülmektedir. Bu kapsamda Türk yönetim sisteminde de birtakım değişiklikler yapılması adeta zorunlu hale gelmiştir. Bunda şüphesiz hem küreselleşmenin getirdiği yerelleşme çabalarının hem de $\mathrm{AB}$ uyum sürecinin etkisi olduğu söylenebilir. Konu ile ilgili bazı çalışmalarda da belirttiği gibi zorunluluğun diğer bir sebebi de kentlerin aşırı büyümesi, çarpık kentleşme, çevre kirliliği ve benzer sorunları mevcut metropol yönetimlerinin kapasite ve kaynakları ile çözmeyi başaramamasıdır. Dünyada birçok ülkede büyüyen kentlerde kentsel alanlarda etkin hizmet sunumu konusunda yeni yönetim şekilleri oluşturulmasında çalışmalar yapıldığ 1 ve yapılmaya devam edildiği bilinmektedir (Gül ve Batman, 2013: 8; Özgür ve Yavuzçehre, 2016: 906). Bilhassa 2000'li y1llardan sonra Türkiye'de özellikle yerel yönetim sisteminde önemli değişimler getiren bazı yeni uygulamalara geçilmiştir.

Yerel yönetim sistemimiz içinde belediyeler, il özel idareleri ve köyler olmak üzere üç tür yerel yönetim şekli vardır. Bu üçlü sistem anayasanın 127/1 maddesinde; “Mahallî idareler; il, belediye veya köy halkının mahallî müşterek ihtiyaçlarını karşılamak üzere kuruluş esasları kanunla belirtilen ve karar organları, gene kanunda gösterilen, seçmenler tarafından seçilerek oluşturulan kamu tüzelkişileridir." şeklindeki tanımda da teyit edilmektedir. Bu yerel yönetimlerden köyler hariç, diğer yerel yönetimlerle ilgili değişiklikler getiren önemli yeni düzenlemelerin sırasıyla 2004, 2005 ve 2012 yıllarında yapıldığı görülmektedir. 2004 yılında 5216 sayılı Kanunla büyükşehir belediyelerinde yeni düzenlemeler yapılmış, 2005 y1lında 5393 ve 5302 sayılı Kanunlarla belediyeler ve il özel idareler ile ilgili köklü değişikler yapılmıştır. Nihayet 2012 y1lında 6360 sayılı Kanunla büyükşehirlerle ilgili değişiklik olarak hem yeni kurulacak büyükşehirlerle ilgili hem de büyükşsehirlerin görev ve sorumluluklarının genişlemesiyle ilgili önemli yeni düzenlemelerin yapıldığı bilinmektedir. Söz konusu bu son Kanun sadece büyükşehirleri ilgilendiren değişiklikler getirmemiş, aynı zamanda büyükşehir yapılan illerde il özel idarelerinin, belde belediyelerinin ve köylerin tüzel kişiliklerini kaldırarak buralarla ilgili önemli değişiklikleri de uygulamaya sokmuştur.

İşte bu kapsamda bu çalışmada önce 6360 sayılı Kanunun yerel yönetim sistemimizde getirdiği genel değişikliklere değinilecek, ardından 6360 sayılı Kanunun büyükşehir belediyelerine ve büyükşehir ilçe belediyelerine yüklediği kırsal görev ve yetkiler anlatılacak, son olarak bu Kanunun kır ve kent alanlarında iç güvenliğe ilişkin getirilen değişiklikler içinde Jandarma'nın görev ve sorumlulukları irdelenmeye çalışılacaktır. Konu ayrıca sonuç ve değerlendirme bölünde de tartışılacaktır.

\section{6360 SAYILI KANUNUN TEMEL GEREKÇESİ VE YEREL YÖNETIM SISTEMINDE YAPILAN ÖNEMLİ DEĞISŞIKLIIKLER}

\subsection{0 sayılı Kanunun Temel Gerekçesi}

Her şeyden önce, bu Kanun en önemli değişiklik olarak, yürürlüğe girmesinden önce İstanbul ve Kocaeli hariç, diğer illerimizin hepsinde mevcut olan üçlü yerel yönetim şeklini yani il, belediye ve köy kademelerinden oluşan yönetim sisteminden ziyade, daha güçlü olacağını ve daha kolay kontrol altında tutabileceğini düşündüğü tek kademeli yani bütün il sınırlarında görev ve sorumluluğa haiz bir büyükşehir modelini benimsemiştir. Böyle bir sisteme geçmenin birçok sorun ve hukuksuzluklara yol açtığı yapılan tartışmalar arasında yer almaktadır. Bu sebepler konusunda Arıkboğa'nın çalışmalarında yaptığı tespitlere göre, Hükümet, bu Kanunu çıkarmak ile üçlü genel sistem ile büyükşehir belediye sisteminin birbirinden tamamen ayrılabileceği düşüncesine dayanarak, 2012 verilerine göre \%70'i beş binden küçük belediyeler ile 35 binden fazla küçük nüfuslu köyün kapanmasını uygun bulmuştur. Bunun yapılma nedeni, bir yerel yönetimin nüfus büyüklüğü ile hizmet etkinliği arasındaki ilişki ve yine bu birimlerin sorumluluğuna verilecek yetkiler arasındaki yakın ilişkidir (Arıkboğa, 2015: 56). Ona göre bir başka sebep olarak kentsel alanlardaki idari parçalanmışlık ve buna bağlı olarak imar, koordinasyon, bütünleşme ve toplumsal eşitlik gibi konularda sorunların ortaya çıkmasıdır. Ayrıca üçüncü sebep olarak da yerel hizmet sunumunda parçalı, küçüklü büyüklü, çoklu sistem yerine daha etkin hizmet sunacağını düşündüğü daha fazla yetkilerle donatılmış büyükşehir ile hizmetlerin tek elden yürütülmesi yeğlenmiştir (Arıkboğa, 2015: 56).

Bir başka gerekçe olarak da dünyadaki pek çok ülkenin büyükşehir yönetimleri konusunda reform çalışmalarına girmiş olmaları ve bu yönetimlerin nasıl olması gerektiği konusunda da tartışmalar çoğalmaktadır. Bu tartışmaların kentsel alanlarla yönetsel sorumluluk alanlarının birbiri ile örtüşmesi gerektiği üzerine yoğunlaşmaktadır. Örnek olarak ise Amerika Birleşik Devletleri, Kanada ve Fransa büyükşehir 
yönetim ölçeğinin genişletildiğinden bahsedilebilir. Yine 19 Avrupa ülkesinde yerel yönetimler üzerinde gerçekleştirilen yeniden yapılanma çalışması yerel yönetimlerde, esas olarak hızlı kentleşme, yapısal, toplumsal ve ekonomik değişimler ve hizmet sunumunda verimliliğe verilen öneme dayanmakta ve 1950 ile 1992 yılları arasında yapılan bu çalışmaya göre bu 19 ülkedeki yerel yönetimin sayısı toplamda 38.933 azalmıştır (Çelikyay, 2014:11).

\subsection{Kanunun Yerel Yönetim Sistemine Getirdiği Önemli Değişiklikler}

Öte yandan 6360 sayılı Kanunun yukarda açıklamaya çalışılan önemli yönetim anlayışı değişikliğinin yanında, Kanunun yürürlüğe girmesiyle birlikte uygulandığı alanlarda bir dizi değişiklikleri de uygulamaya sokmuştur. Bu anlamda Kanunun 2014 mahalli idare seçimlerinden sonra yürürlüğe girdiğinde daha önce 16 olan büyükşehir sayısı 750 bin nüfus kriterini sağlayan illerle 30'a çıkarılmıştır.

12 Kasım 2012’de 6360 sayılı “On Üç İlde Büyükşehir Belediyesi ve Yirmi Altı İlçe Kurulması ile Bazı Kanun ve Kanun Hükmünde Kararnamelerde Değişiklik Yapılmasına Dair Kanun” kabul edilmesiyle bu Kanun kapsamında; Aydın, Balıkesir, Denizli, Hatay, Malatya, Manisa, Kahramanmaraş, Mardin, Muğla, Tekirdağ, Trabzon, Şanlıurfa, Van'ın il belediyeleri, büyükşehir belediyelerine dönüştürülmüştür. Ordu ise daha sonra 6447 sayılı Kanunla büyükşehir statüsüne kavuşturulmuştur.

Çelikyay (2014: 12) 6360 sayılı Yasa ile gelen değişiklikleri maddeler halinde şöyle özetlemiştir:

1. 13 ilde yeni büyükşehir belediyesi kurulmuştur (daha sonra Ordu ili eklenerek say1 14'e ç1karılmıştır). Toplam büyükşehir sayısı 30 olmuştur,

2. Bütün büyükşehir belediye sınırları il sınırı olmuştur,

3. 30 ildeki il özel idareleri kaldırılmıştır,

4. Yeni ilçeler kurulmuştur,

5. Büyükşehirlerdeki bütün ilçe belediyelerinin sınırı mülki sınır olmuştur,

6. Bu illerdeki bütün belde belediyeleri kaldırılmış ve bunlar bir belediyenin mahallesine dönüştürülmüştür,

7. Bu illerdeki bütün köy yönetimleri kaldırılmış ve bunlar mahalle yapılmıştır,

8. Büyükşehir belediyeleri dışındaki illerde nüfusu 2.000 'den az olan belde belediyeleri köye dönüştürülmüştür,

9. Mülki idareye bağlı olarak 30 ilde, Yatırım İzleme ve Koordinasyon Başkanlığı kurulmuştur,

10. Merkezi yönetim payları yeniden düzenlenmiştir.

Yapılan bu değişiklikler arasında 30 ildeki il özel idareleri kaldırıldığını görüyoruz. Zira bir yerel yönetim oluşturulurken diğerinin kaldırılması önemli bir değişiklik getiriyor. Dolayısıyla bu Kanuna dayanarak kurulan bu 30 büyükşsehir belediyesinde bulunan il özel idarelerinin tüzel kişilikleri kaldırılmıştır. Gül ve Batman'a (2013: 33) göre bu Kanunla 150 yıllık geçmişe sahip il özel yönetimleri kaldırılmakta ve görevleri çok karmaşık bir şekilde değişik yönetim birimlerine dağıtılmaktadır. Bu kapsamda il özel yönetimlerinin görevleri "ilgisine göre bakanlıklara, bakanlıklara bağlı veya ilgili kuruluşları ile bunların taşra teşkilatına, Hazineye, valiliklere, büyükşehir belediyelerine ve ilçe belediyelerine yapılmış sayılır" denmektedir. Fakat görevlerin çoğu büyükşehir belediyelerince yapılacaktır. Bu uygulama sonucu olarak 30 büyükşehir belediyesinde il valisine bağlı olarak Yatırım İzleme ve Koordinasyon Başkanlıkları kurulmuştur. Bunun yapılmasının gerekçesini (Çelikyay (2014: 12) şöyle açıklamaktadır: "6360 sayılı Yasa'nın kabul edilmesine kadar büyükşsehirlerde 2005 yılında çıkarılan İl Özel İdaresi Kanunu ile il özel idarelerinin kuruluş, görev, sorumluluk ve organları geniş şekilde belirlenmiş, böylelikle il özel idareleri ile büyükșehir belediye yönetimi kentin yönetiminden sorumlu olmuşlardır. Her iki yönetimin de kent üzerinde söz sahibi olduğu bazı görev ve kararlar zaman zaman yönetimde etkinliği ve kaynakların verimli kullanımını zora sokmuştur. Bu durum kentin yönetiminde tek gücün ve tek yetkinin kullanılmasını zorlaştırmıştır. İl özel idarelerinin birçok görevi, aynı zamanda büyükşehir belediyeleri tarafindan da yerine getirilmektedir."

Başka önemli yenilik olarak belde belediyelerinin kapatılması ya da mahalle veya köye dönüştürülmesi zikredilebilir. Bu kapsamda bu Kanun ile büyükşehir sınırları içindeki belde belediyeleri ve orman köyleri 
dâhil köylerin tüzel kişilikleri kaldırılmakta, büyükşehire dönüştürülecek illerde en az bir ilçe kurulmakta, büyükşehir olmayan 51 ilde, nüfusu 2.000'in altındaki belde belediyelerinin tüzel kişiliğine son verilmektedir (Çelikyay (2014: 16). Yine kurulan bu 30 büyükşehir sınırları içindeki köylerin tüzel kişiliği kaldırılarak mahalleye dönüştürülmesi de bu değiş̧iklikler arasındadır. Nihayetinde Kanun 30 il özel idaresi, 1591 belde belediyesi ile 16.082 köyün tüzel kişiliğini sona erdirirken, büyükşehir sınırlarındaki beldeleri ve köyleri mahalleye dönüştürerek ilçe belediyelerine bağlamakta ve diğer illerde tüzel kişiliği sona erdirilen belde belediyelerini de köye dönüştürmektedir. Burada dikkat edilmesi gereken bir husus ise Kanun ile belde belediyeleri ile ilgili iki farklı yöntemin kabul edilmiş olmasıdır: Birincisi, büyükşehir belediyesine dönüşen illerdeki belde belediyelerinin mahalleye dönüştürülmesi, ikincisi de büyükşehir belediyesi olmayan illerde nüfusu 2000'nin altına düşen belde belediyelerinin kapatılıp köye dönüştürülmesi durumudur (Çelikyay (2014: 16).

Tablo 1. 6360 sayılı Kanun öncesi ve sonrası değişen yerel yönetim sayıları

\begin{tabular}{|l|c|c|}
\hline Yerel Yönetimler & $\begin{array}{c}\text { 6360 Sayılı Yasa } \\
\text { Öncesi }\end{array}$ & 6360 Sayılı Yasa Sonrası \\
\hline Büyükşehir Belediyesi & 16 & 30 \\
\hline Büyükşehir İlçe Belediyesi & 143 & 501 \\
\hline İl Belediyesi & 65 & 51 \\
\hline İlçe Belediyesi & 749 & 416 \\
\hline Belde Belediyesi & 1977 & 395 \\
\hline Belediye Sayısı Toplam & 2950 & 1392 \\
\hline İl Özel İdaresi Sayısı & 81 & 51 \\
\hline Köy İdareleri & 34283 & 17720 \\
\hline
\end{tabular}

KAYNAK: Çelikyay, 2014: 16

Şüphesiz 6360 sayılı Kanunla oluşturulmak istenen güçlü büyükşehir sisteminde gelirlerle ilgili de önemli değişikliklerin yapıldığı ve büyükşehir yönetiminin lehine gelir artışının olduğu görülmektedir. $\mathrm{Bu}$ kapsamda genel bütçe vergi gelirleri tahsilatı toplamından büyükşehir dışındaki belediyelere verilen pay \% 2,85 'ten \% 1,5'e ve il özel yönetimlerinin payı da \% 1,15’ten \% 0,5'e çekilmiştir. Diğer taraftan, 5779 sayılı Yasaya göre, genel bütçe vergi gelirleri tahsilatı toplamından büyükşehirdeki ilçe belediyelerine verilen pay $\%$ 2,5'ten \% 4,5'e yükseltilmektedir. Ayrıca, yine 5779 sayılı Yasa gereği büyükşehir belediye sınırları içinde yapılan genel bütçe vergi gelirleri tahsilatından büyükşehir belediyelerine aktarıla pay \% 5 'ten \% 6'ya çıkarılmakta ve genel bütçe vergi gelirleri tahsilatı toplamı üzerinden büyükşehirdeki ilçe belediyelerine ayrılan payların yüzde 30'u, nüfus ve yüzölçümü temelinde yine büyükşsehir belediyelerine aktarılacaktır (Gül ve Batman, 2013: 34; Zengin, 2014: 104).

\section{6360 SAYILI KANUNUN BŞB VE ILÇE BELEDIYYELERİNE YÜKLEDİĞİ KIRSAL GÖREV VE YETKILER}

Bilindiği üzere 2000'li yıllardan sonra hem dünyada hem de ülkemizde gerçekleştirmeye çalışılan bir takım yeni yönetim modellerinin geliştirilmesi ve uygulanmaya konma çalışması alanlarından birisi büyük yerleşim yerleri için metropoliten yönetime geçilmesidir. 2004 ve 2012 yıllarında yapılan yasal düzenlemelerle yerel yönetimlerin yetki alanı ve sorumlulukları genişletilmiştir. Dolayısıyla 2004 yılında çıkarılan 5216 sayılı Büyükşehir Belediye Kanunu ile belediyelerin yetki alanına kırsal alanlar da dahil edilmiş, 2012 yılında çıkarılan 6360 sayılı Kanun ise büyükşehir beledilerini ve büyükşehir ilçe belediyelerini kırsal ve kentsel nitelikli alanları kapsayan ve sınırları il sınırlarına dayandırılan alanın tamamında yetkili kılarak büyükşehir yönetiminin görevlerini il mülki sınırlarına kadar genişletmiştir (Yenigül, 2016: 292). Böylece büyükşehir belediyesi sınırlarının mülki sınırlar olmasıyla, belediye sınırlarına dahil edilen kırsal alanlardan ötürü büyükşehir ve ilçe belediyelerine, tarım ve hayvancılığın geliştirilmesine yönelik çeşitli hizmet ve faaliyetler yapabileceği hükmü 5216 sayılı Kanun'a eklenmiştir. 2012 yılında 6360 sayılı Kanun TBMM'de kabul edildiğinde belde ve köy nüfusunun toplam nüfus içindeki oranı \% 22,7 olarak görünürken, bu oran 2013 ve 2014 de düşüş göstermiş, $2013 \%$ 8,7 ve 2014 \% 8,2 olmuştur. İl ve ilçe merkezleri olarak kent nüfusunda ise artış olmuştur. Sırasıyla artış \% 77,3’ten \%91,3 ve ardından da \%91.8'e yükselmiştir (Zengin, 2015: 7). 
Ülkemizde belediyelerin yetki ve görevlerini düzenleyen yasalar $(5393,5216,6360$ sayılı yasalar) görevleri bakımından incelendiğinde daha çok imarla ilgili düzenlemelere ağırlık verildiği söylenebilir. Söz konusu yasalar tarıma yönelik görevlere yer verip vermediğine bakıldığında sadece birer maddesinde "tarım" kelimesine yer verildiği örneğin 5393/69, 5216/7 ve 6360/14 gibi ve bu maddelerde imara yönelik düzenlemeler yapılırken tarım alanların korunacağı hükmü dışında bir hükme yer verilmediği görülmektedir. 6360 sayılı son yasal düzenlemeyle kent yönetimine dahil edilen tarım alanların nasıl korunacağına dair ve bu alanlarda yapılacak tarımsal faaliyetlerin geliştirilmesi konusunda yerel yönetimlerin hangi yolu izleyeceği ve ne yapacağı konusunda bir netlik yoktur. Bu konuda yapılan tek şey Kanunun 2014 Nisan'ında yürürlüğe girmesinden sonra, bu Kanunun ile kurulan yeni büyükş̧ehir belediyeleri de faaliyetlerine başlamışlardır. Bu kapsamda yeni düzenlemeye göre büyükşsehir belediyeleri kırsal alana yönelik görevleri ile ilgili " kırsal hizmetler' ya da 'tarımsal hizmetler' adında daire bașkanlıklarını kurmuşlardır. Ardından da kurulan bu birimin görev ve sorumluluklarının tanımlanmasına yönelik yönetmelikler çıkarılmıştır. Söz konusu yönetmeliklere göre bu daire başkanlıklarının görevleri; "kırsal bölgelerde sosyal yaşamı, tarım ve hayvancılığı desteklemek amacı ile her türlü faaliyet ve hizmette planlama, uygulama ve koordinasyonunu sağlayıp sonuçlandırmak, kırsal kalkınmayı desteklemek amacıyla verilen her türlü faaliyet ve hizmetle ilgili görev, yetki ve sorumlulukları yerine getirmek" şeklinde tanımlanmaktadır (Yenigül, 2016: 297). Bu görev tanımına göre, tarımsal faaliyetlerin kırsal odaklı yaklaşımla ele alındığı ve kırsal kalkınmanın bir bileşeni olarak görüldüğü söylenebilir.

\section{6360 SAYILI KANUN İLE JANDARMA TEŞKILATI ARASINDAKİ İLISŞIIYE YÖNELIK NITEL BİR ARAŞTIRMA}

6360 sayılı Kanunla birlikte büyükşehir statüsü kazanmış Manisa ve Balıkesir illerinde Jandarma Teşkilatında görev yapan 5 jandarma personeli ile yapılan görüşmelere ilişkin veri ve değerlendirmelere aşağıda yer verilmiştir.

\subsection{Araștırmanın Alanı ve Amacı}

Araştırmanın alanının Manisa ve Balıkesir illerinde Jandarma Teşkilatında görev yapan jandarma personeli oluşturmaktadır. Araştırmanın amacı ise, yeni büyükşehir statüsü kazanmış Manisa ve Balıkesir şehirlerinde çalışan jandarma personelinin 6360 sayılı kanunla birlikte görevlerine ilişkin bilgi ve tutumlarını ölçmek, 6360 sayılı Kanunun geleceğine yönelik düşüncelerini ortaya koymaktır. Bu amaç ile jandarma personeliyle birebir görüşülmüştür. Nitel araştırma yönteminin kullanıldığı bu çalışmada, yarı yapılandırılmış sorular çerçevesinde görüşmeler gerçekleştirilmiştir.

Bu çalışmada 5 jandarma personeliyle birebir yüz yüze görüşülmüş ve bu kişilere kendileriyle ve konuyla ilgili toplam 4 soru sorulmuştur. İlgili kişilere sorulan sorular şu şekildedir:

Soru 1: Jandarmanın görev alanını net olarak tanımlayabilir misiniz?

Soru 2: Jandarmanın 30 büyükşehir dışında görev alanları, sorumlulukları, yetkileri ile büyükşehirlerde görevleri arasında bir fark var mıdır?

Soru 3: Size göre jandarma iç güvenlik konusunda büyükşehir alanlarında görev üstlenmeli midir?

Soru 4: 6360 say1lı Kanunun revize edilmesini ihtiyaç olarak görüyor musunuz?

Çalışmada derinlemesine görüşme yapılan katılımcılara ilişkin tanıtıcı bilgiler aşağıdaki Tablo 2 de sunulmuştur:

Tablo 2. Katılımcıların demografik bilgileri

\begin{tabular}{|l|l|l|l|}
\hline Katılımclar & cinsiyet & tecrübe & eğitim \\
\hline A1 & Erkek & 9 & lisans \\
\hline A2 & Erkek & 20 & lisans \\
\hline A3 & Erkek & 17 & Yüksek lisans \\
\hline A4 & Erkek & 19 & Yüksek lisans \\
\hline A5 & Erkek & 26 & lisans \\
\hline
\end{tabular}




\subsection{Araştırmanın Veri Toplama Araçları}

$\mathrm{Bu}$ araştırmada veri toplama yöntemi olarak nitel araştırma tekniklerinden birisi olan yarı yapılandırılmış görüşme yöntemi kullanılmıştır. Bu yöntem yapılandırılmış görüşmeler gibi katı olmayıp, aynı zamanda yapılandırılmamış görüşmeler kadar da esnek değildir. Her iki yöntemin tam ortasında yer almaktadır (Karasar, 1995:165). Jandarma personeline yöneltilecek görüşme soruları hazırlanmadan önce literatür taraması yapılmış ve görüşme formunda yer alması düşünülen sorular belirlenmiştir. Araştırmaya ilişkin veriler Manisa ve Balıkesir Jandarma Teşkilatında görev yapan personel ile 01 Mart 2019-30 Mart 2019 tarihleri arasında görüşülerek veri toplanmıştır.

\subsection{Araştırmanın Sınırlılıkları}

Araştırmanın sınırlılıklarını, Jandarma Teşkilatı bünyesinde çalışan personelin arazide gezen ekip olarak çalışması dolayısıyla ulaşılmasının zor olması ve her bir personelin yoğun bir iş temposu dâhilinde çalışması oluşturmaktadır. Ayrıca jandarma personelinin güvenlik politikalarında görev yapmaları; DSİ, Ticaret İl müdürlügü gibi sivil bürokrasiye nazaran anket, mülakat gibi birebir bilimsel çalışmaların yapılabilmesi önemli bir kısıt oluşturmuştur.

\section{BULGULAR VE TARTIŞMA}

Söz konusu 6360 sayılı Kanun yukarıda anlatıldığı üzere birçok konularda yenilikler getiren bir düzenlemedir. İşte bu yeniliklerden önemli bir tanesi de iç güvenlikle ilgili olduğu söylenebilir. Bu anlamda iç güvenlik daha çok devletin sınırları içerisinde güvenlik koşullarının sağlanması anlamına gelmekte ve bu güvenlik de askeri örgütlenme sayılmayan başta polis ve jandarma silahlı güvenlik örgütlenmeleri tarafından sağlanmaktadır (Barbak, 2017: 232).

Barbak'a göre, iç güvenlik ve iç güvenlik yönetimi, 20'nci yüzyılın sonundan itibaren değişmeye başlamış ve 2000 den sonra $A B$ ülkeleri ve $A B D$ de bu değişime rastlamak mümkündür. Devletlerin birçok alanda kullandığı politika aracını, iç güvenliğin örgütlenmesinde de görebiliriz. Güvenliğe ilișkin olușturulan yasal düzenlemeler merkezi yönetim ve yerel yönetim açısından birtakım sonuçları olan politika değişikliklerini kapsamaktadır. Bu anlamda iç güvenlik örgütlenmeleri zamandan zamana ve coğrafyadan coğrafyaya göre değişiklik gösterebilmektedir. İç güvenlik devletin güvenlik alanında sunduğu önemli ve vazgeçemeyeceği bir kamu hizmeti olması hasebiyle, devletin iç güvenlik örgütlerini oluşturması da zorunlu hale gelmektedir ( Barbak, 2017: 232-234).

Ülkemizde iç güvenlik konusuna yönelik olarak ülke genelinde emniyet ve asayişin sağlanmasını amaçlayan bazı kanunlar çıkarılmıștır. Bunlardan en belirgin olan birisi 3201 sayılı Emniyet Teşkilatı Kanunudur. Söz konusu kanunun 1.maddesinde iç güvenliğe ilişkin şu ifadelere yer verilmiştir: "Memleketin umumi emniyet ve asayişinin sağlanmasından İçişleri Bakanı sorumludur, İçişleri Bakanı bu görevi kendi kanunları dairesinde hareket eden Emniyet Genel Müdürlügü ve Jandarma Genel Komutanlığı ve gerektiğinde de bütün zabıta teşkilatı vasıtası ile ifa eder.” Öte yandan 3152 sayılı İçişleri Bakanlığının Teşkilat ve Görevleri Hakkındaki Kanunun 2. maddesinde İçişleri Bakanının görevleri şöyle sayılmıştır: "Bakanlığa bağlı iç güvenlik kuruluşlarını idare etmek suretiyle ülkesi ve milleti ile bölünmez bütünlügünü, yurdun iç güvenliğini ve asayişini, kamu düzenini ve genel ahlakı, Anayasada yazılı hak ve hürriyetleri korumak; sınır, kıyı ve karasularımızın muhafaza ve emniyetini sağlamak; karayollarında trafik düzenini sağlamak ve denetlemek; suç işlenmesini önlemek, suçluları takip etmek ve yakalamak; her türlü kaçakçılığı men ve takip etmekle" İçişleri Bakanı görevlidir (Doğan, 2010: 25). Kanunun 5.maddesine göre, "Bakan, Bakanlık kuruluşunun en üst amiridir, emri altındakilerin faaliyet ve işlemlerinden sorumludur" ifadesiyle İçişleri Bakanına iç güvenliğin sağlanması görevi ve sorumluluğu verilmiştir. Böylece İçişleri Bakanlığının Türk idari sisteminde esas görevi ülkenin emniyet ve asayişini sağlamaktır. İçişleri Bakanı'nın emniyet ve asayişi sağlama araçları ise Jandarma Genel Komutanlığı ve Emniyet Genel Müdürlüğüdür. Bu düzenlemelerden ülkenin emniyet ve asayişinden İçişleri Bakanı hem kişisel hem de siyasal anlamda sorumlu olduğu anlaşılmakta ve yetkinin farklı makamlara verilmeyerek tek bir makama verilmesi ile de yetki dağılımının önüne geçilmek istendiği söylenebilir. Polis teşkilatının görev ve yetkilerini düzenleyen esas kanun ise 4 Temmuz 1934 tarih ve 2559 sayılı Polis Vazife ve Salahiyetleri Kanunudur. Bu kanunun 2.maddesine göre, polis, şehir ve kasabaların emniyet ve asayişinden sorumlu kolluk kuvvetidir. Bu kapsamda polis sorumlu olduğu bölgede, kamu düzeninin ve kamu güvenliğinin sağlanmasından sorumludur. Polisin genel emniyetle 
ilgili iki görevi şöyledir: 1.Önleyici kamu hizmetlerini ifa etmek yani suç işlenmesine mani olmak, 2. İşlenmiş olan bir suç hakkında kanunlarda yazılı görevleri yapmaktır (2559 sayılı PVSK Md.2; Doğan, 2010: 38).

"Emniyet ve Asayiș İşlerinde İl, İlçe ve Bucaklardaki Jandarma ve Emniyet Ödevlerinin Yapılması ve Yetkilerinin Kullanılması Suretini ve Aralarındaki Münasebetleri Gösterir Yönetmelik" 15/7/1961 tarihinde 10855 say1lı Resmi Gazetede yayınlanarak yürürlüğe girmiş ve daha sonra 25/3/2009-2009/14809 K. sayı ve tarihle yapılan değişikliğe göre Jandarma ve Polisin görevleri şöyle belirlenmiştir: "Esas olarak il ve ilçe belediye sınırları içindeki bölge polisin sorumluluk alanını; il ve ilçe belediye sınırları dışında kalan bölge ise jandarmanın sorumluluk alanını oluşturur. Kolluk birimlerinin personel, araç, gereç imkânları ve hizmet gerekleri göz önünde bulundurularak belediye sinırları dışında kalan yerlerden bir kısmı polisin görev alanı; belediye sınırları içinde olmakla birlikte şehir meskûn alanlarına uzak bazı yerler ise jandarmanın görev alanı olarak tespit edilebilir."

Jandarma'nın görev ve yetkilerini düzenleyen kanunlardan birisi 2803 sayılı Jandarma Teşkilat Görev ve Yetkileri Kanunudur. Bu kanunun 3.maddesinde; "Türkiye Cumhuriyeti Jandarması, emniyet ve asayişi ile kamu düzeninin korunmasını sağlayan ve diğer kanun ve nizamların verdiği görevleri yerine getiren silahlı, askeri bir güvenlik ve kolluk kuvveti” olduğuna yer verilmiştir. Aynı kanunun 10. maddesine göre, Jandarmanın genel olarak görev ve sorumluluk alanı; Polis görev sahası dışı olup, bu alanlar il ve ilçe belediye hudutları haricinde kalan veya polis teşkilatı bulunmayan yerlerdir. Öte yandan 1706 sayılı Jandarma Kanununun 1.maddesinde ise "Türkiye Cumhuriyeti Jandarması umumi emniyet ve asayişi korumaya, kanun ve nizam hükümlerinin icrasını teminine ve bunlara müstenit hükümet emirlerini ifaya memur edilen bir inzibat kuvveti” olduğu ifadesini görmekteyiz. Doğan (2010: 53) Jandarma'nın genel kolluk kuvveti olduğunu ve bizzat idare kuvvetinin içinde yer aldığını belirtiyor. Ona göre, askeri kuvvetler sivil idarenin emri altında olmazken, jandarma bir askeri kuvvet olduğu halde sivil idarenin emrinde çalışır ve ona bağlıdır.

Jandarma Kanunu 5. maddesine göre, Jandarma esas itibariyle kırsal bölgelerde görev yapan kolluk kuvvetidir. Fakat polis teşkilatı bulunmayan yerlerde de kolluk hizmeti jandarmaya düşmektedir. Jandarmanın görev ve sorumluluk alanı, genel olarak polis görev ve sorumluluk alanı dışında kalan bölgedir. Dolayısıyla bu alan, il ve ilçe belediye sınırları dışında kalan ve polis teşkilatı bulunmayan yerleri kapsar. Jandarmanın görev ve sorumluluk alanı Jandarma Kanunu'nun 10.maddesinde de 2803/10 daki gibi tanımlanmaktadır: "jandarmanın genel olarak, görev ve sorumluluk alanı, polis görev ve sahası dışı olup, bu alanlar il ve ilçe belediye hudutları haricinde kalan ve polis teşkilatı bulunmayan yerlerdir."

Çalışmamızda jandarma personeline yöneltilen ilk soru "Jandarmanın görev alanını net olarak tanımlavabilir misiniz?" olmustur. Görüsülen A1 jandarma personeli bu soruya "Mülki taksimatla belirlenmiş, Polis bölgesi dışında kalan tüm mahalle ve mücavir alanlar jandarma sorumluluk bölgesidir." demek suretiyle jandarmanın görev alanını polis teşkilatına göre konumlandıran yukarıdaki Jandarma Kanunun 5.maddesine uyumlu yaptığı görülmüştür.

Görüşülen A2 ise "2803 Jandarma teşkilat kanunun 7 maddesinden de anlaşılacağı üzere aslında jandarmanın net bir görev alanı yoktur. Bulunduğu ve konuşlandığ yer ve duruma göre görev alanları belirlenmektedir." diyerek kanunun bu konuda bir boşluk barındırdığını ifade etmektedir.

A3 jandarma personeli bu soruya "Genel olarak belediye sınırları dışında ancak mülki makamlar onayıla belirlenmiş bölgelerde jandarma ve polis genel kolluk görevleri yürütülmektedir.” cevabı vererek mülki makamın bu hususla ilgili olarak yetkili olmasını işaret etmiştir.

A4 ise "Jandarmanın görev alanı asayiş hizmetleri bakımından kent merkezinden uzak alanları kapsamaktadır." demek suretiyle Fransa'da tarihsel süreçte ortaya çıktı̆̆ 1 üzere esasında jandarmanın tabiatında kırsal alana hizmet götürmenin bulun-duğuna vurgu yapmıştır.

Doğan’a (2010: 53) göre, “Jandarma Genel Komutanlı̆ğ iç güvenlik birimlerinin görev ve sorumluluk alanı iki önemli esasa bağlıdır. Birincisi 'il ve ilçe belediye sinırları', ikincisi ise 'polis teşkilatıdır.' Il ve ilçe belediye sinırları dışında kalan coğrafi alandaki genel kolluk görevlerinin yürütülmesinden JGK sorumludur. Ayrıca, polis teşkilatı kurulamayan yerlerde jandarma il ve ilçe belediye sınırları içinde olsa bile, oradaki genel kolluk hizmetlerinin tümünü yürütmekle görevlidir. Bu konuda İçişleri Bakanlı̆̆ı'nca emir verilmeksizin jandarma otomatik olarak bu görevi yürütür. Her ilçede bir Jandarma Bölük Komutanlı̆̆ kurulması zorunludur. Ancak, emniyet amirliği bulunmayan ilçelerde de yasal olarak polisin görevlerini jandarma üstlenir." 
Yukardaki bilgiler doğrultusunda şu sonuca varmak mümkündür. Kolluk kuvvetlerinin görev yaptıkları bölge konusunda genel kural polis teşkilatı olmayan yerlerde jandarma görev alabilir. Ancak kentleşmenin artmasına bağlı olarak polis teşkilatının daha çok görev alabileceği ve böylece jandarmanın da belediye sınırları içine giren bu bölgelerde görevini polise devretmesi esastır. Ayrıca Emniyet Teşkilatı Kanunu madde 16/b fikrasına göre, İçişleri Bakanlığı'nın uygun göreceği yerlerde polis teşkilatı kurulabilir.

27/3/2015 tarihinde kabul edilen 6638 sayılı Polis Vazife ve Salâhiyet Kanunu, Jandarma Teşkilat, Görev ve Yetkileri Kanunu İle Bazı Kanunlarda Değişiklik Yapılmasına Dair Kanun incelendiğinde polis ve jandarmayı ilgilendiren bir dizi değişiklik yapıldığı görülmektedir. Ancak jandarmanın görev alanına ilişkin düzenlemeye sadece bir maddede ek cümleyle yer verilmiştir. Bu anlamda Kanunun 49.maddesinde, 2803 sayılı Kanunun 10 uncu maddesinin birinci fikrasına şu cümle eklenmiştir: "Ancak, belediye sınırları içinde olmakla birlikte hizmet gerekleri bakımından uygun görülen yerler, jandarmanın görev ve sorumluluk alanı olarak tespit edilebilir." Daha sonraki yıllarda ise 2803 sayılı Kanunda yapılan birtakım değişiklik ve eklemeler şunlardır: (Ek cümle: 25/7/2016-KHK668/11 md.; Aynen kabul: 8/11/2016-6755/11 md.) İçişleri Bakanının kararıyla bir il veya ilçenin tamamı polis ya da jandarma görev ve sorumluluk alanı olarak belirlenebilir. (Ek fikra : 15/8/2017/KHK-694/52 md.; Aynen kabul: 1/2/2018-7078/49 md.) İl ve ilçelerdeki jandarma ve polis sorumluluk alanlarının sınırları, ilçelerde kaymakam, illerde vali veya görevlendireceği vali yardımcısı başkanlığında jandarma ve emniyet temsilcilerinin katılacağı bir komisyon tarafından belirlenir. Komisyon, vali veya kaymakamın çağrısı üzerine toplanır. Büyükşehir, il veya ilçe belediyesi kurulması, kaldırılması ya da kentleşme veya diğer sebeplerle sınırlarda değişiklik olması halinde, değişikliğin yürürlüğe girdiği tarihten itibaren en geç üç ay içerisinde sorumluluk alanları yeniden düzenlenir. Komisyon tarafindan alınan kararlar İçişleri Bakanının onayıyla yürürlüğe girer. Belirlenen sorumluluk alanlarının sınırları karara eklenen bir harita veya kroki üzerinde gösterilir. Jandarma, kendisine verilen görevlerin ifası ile ilgili olarak diğer güvenlik kuvvetleri ile işbirliği ve koordinasyonda bulunur. Jandarma veya Emniyet Teşkilatı, kendi sorumluluk sahasında yetersiz kaldıkları veya kalacaklarının değerlendirilmesi halinde, mahalli mülki amirler tarafından birbirlerinin sorumluluk sahalarında geçici olarak görevlendirilebilirler. Jandarmanın diğer güvenlik kuvvetleriyle işbirliği ve koordinasyon esasları ve emir komuta ilişkileri yönetmelikle belirlenir.

Jandarma personeline ikinci soru olarak "Jandarmanın 30 büyü̈şsehir dışında görev alanları, sorumlulukları, yetkileri ile büyükş̧ehirlerde görevleri arasında bir fark var mıdır?” yöneltilmiştir. Bu soruya tüm katılımcıların aynı cevabı vermiş olması dikkat çekicidir. A1 bu soruya "Büyükşsehir yâda şehir olması arasında jandarmanın görev ve sorumluluklarını etkileyecek bir fark yoktur." demiştir. A2 benzer biçimde "Aslında bu hususta görevleri arasında bir fark olmadığını düşünüyorum. Jandarma Kanunu madde 8'e göre görevleri tanımlanmıștır. Bu madde gereği ister Büyükşehir olsun ister olmasın görevini en layık şekilde yerine getirecektir." demek suretiyle Al'in düşüncesini desteklemiştir.

Kanunlar ve yönetmelikler polis ve jandarmanın görev alanını il ve ilçeyi baz alarak kent alanlarında polisin, kent dışı alanlarda ise jandarmanın görevli olacağını belirlemiştir. Ancak Gözler bu konuda şöyle bir iddia geliştirmiştir. Ona göre, "kolluk mevzuatımız, bir il veya ilçede belediye sınırlarına dâhil olmayan yerlerin olacağını varsayarak düzenleme yapmıştır. Oysa 6360 sayılı Kanun, köyleri mahalle-ye dönüştürerek ve ilçe mülki sınırları ile ilçe belediyesinin sınırlarını örtüştürerek bu varsayımı yıkmıştır" (Gözler, 2013: 69). Öte yandan 6360 sayılı Kanuna yönelik ve bilhassa jandarmanın görevli olduğu yerlerin yani köylerin mahalleye dönüştürülerek polise bırakılmasını Gözler bir başka açıdan da eleştirmektedir. Bu eleştirisi daha çok polis ve jandarmanın hizmet alanlarında kullandıkları hizmet araçlarının teknolojisinin çok çok faklı olmasına yöneliktir. Bu anlamda Gözler Polisin sahip olduğu araç parkı ve silahlar köylerde ve dağlarda kolluk hizmetinin yürütmek için elverişsiz olduğunu savunuyor. Ona göre, "Şehirde polisin normal bir otomobile ihtiyacı vardır. Kırdaki kolluk görevlisinin ise bir arazi taşıtına ihtiyacı vardır. Şehirdeki hırsızı yakalamak için normal bir tabanca yeterlidir; ama dağdaki haydudu yakalamak için uzun namlulu silaha ihtiyaç vardır. Ayrıca personel sayısı bakımından ortaya ciddi bir problem çılkacaktır” (Gözler, 2013:69).

Jandarma personeline yöneltilen "Size göre jandarma iç güvenlik konusunda büyükşehir alanlarında görev üstlenmeli midir?" sorusuna yönelik A1 katılımcısının verdiği cevap "Zaten terörle mücadele, cezaevi diş koruma, iç güvenlik gibi çok çeşitli alanlarda sorumluluğu olan jandarmaya, zeminini hazırlamadan, yeterli personel, araç vb. vermeden daha fazla görev yüklemenin uygun olduğunu düşünmüyorum. " yukarıda yer alan Gözler'in yorumlarıyla birlikte değerlendirilmesi gereken bir husustur.

Diğer katılımcıların bu soruya verdiği cevaplar ise A1'in düşüncesinin aksi istikametinde olmuştur. A2 bu soruya "Jandarma personeli vatan sevgisi fedakârlık ile görevini yerine getirmektedir. Bulunduğu 
şartlar ve durum ne olursa olsun görevini en iyi şekilde yerine getireceğine inancım tamdır." demiştir. A3 ve A4 ise sirasıyla "Evet üstlenmelidir. Halen mevcut görevlerine mahallelerde de devam etmektedir." ve "Evet üstlenmelidir." demiştir.

Katılımcılara son soru olarak "6360 sayılı kanunun revize edilmesini ihtiyaç olarak görüyor musunuz?" yöneltilmiştir. A1 bu soruya "eskiden köy statüsündeki kirsal mahallelere, hizmet götürme

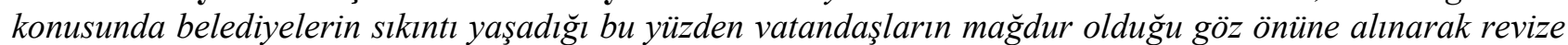
edilmeli." diyerek kanunun kırsal alan yönetimi konusundaki noksanlığına değinerek revize edilmesi fikrini beyan etmiştir. A2 ise "6360 sayıl Kanun eski adıyla köylerin bu kanunla mahalle oluşu ve hizmetlerin daha yayginlaşmast ve isteklerin daha hızlı çözümü noktasında yarar sağlarken, yerel belediyelerin hizmet etmesi gereken alanları daraltmış ve (bu vatandaşın gözüyle yerel belediyelerin çalışmadığı düşüncesi hasıl oluyor diye düşünüyorum)" A1'in düşüncesinin tersine köylerin ve kırsal alanların anakent belediyelerce hizmetlere erişebildiğini ancak bu durumun metropol ilçe belediyelerini aslında sıkıntıya düşürdügünü iddia etmiştir.

A3 ise "Etki alanının genişlemesini tüm illerde veya nüfus kriterinin 500.000 olarak düzenlenmesinin gerekli olacağını düşünüyorum.” demek suretiyle bu uygulamanın genişlemesini savunmuştur. A4 bu soruya "Güvenlik ve asayiş hizmetleri konularında polis ve jandarma ortak hareket edebilecekleri konuların artırılması, bunun yanında hizmet sunumu ve hizmet maliyetinin düşürülmesi açısından 6360 revize edilmesi gerektiğini düşünüyorum." demek suretiyle kanunun revize edilmesi gerekliliğini söylemiştir.

\section{SONUÇ VE ÖNERILER}

Büyükşehir yönetim modelleri üzerinde Dünya genelinde önemli çalışmaların yapılmakta olduğu bilinmektedir. Yapılan bu çalışmaların en önemli amaçları arasında büyük yerleşim alanlarında hizmet sunumunu daha etkin ve verimli sunabilecek yönetim modellerine gereksinim duyulmasıdır. Çünkü söz konusu bu büyük yerleşim yerlerinde nüfusun çok yoğun olması ve alanın geniş olması, bu alanlarda küçük şehirlerde rastlanmayan ulaşım, çevre ve hava kirliliği, yoksulluk, suç oranının artması ve konut gibi pek çok sorunları da beraberinde getirmektedir. İşte bu büyük yerleşim yerlerinde artan bu sorunların çözülmesini sağlayabilecek güçlü büyükşehir yönetimlerinin oluşturulması en önemli gerekçelerden olduğu söylenebilir. Nitekim bu gerekçeyi 6360 sayılı Kanunun gerekçeleri arasında da görmek mümkündür. Bu kapsamda 6360 sayılı Kanunun çıkarılması ile Dünya'da yapılan model arayışlarına paralel olarak Türkiye'de de bir yeni model geliştirilmeye çalışıldığı söylenebilir. Bu anlamda söz konusu kanun yürürlüğe girdikten sonra büyükşehir yönetimlerinin görev ve yetkilerine bir takım yenilikler eklendiği görülmektedir. 6360 sayılı Kanun yürürlüğe girmesi ile birlikte 30 büyükşehirdeki il özel idarelerinin tüzel kişiliğine son verilerek, özel idarelerin yürüttüğü hizmetlerin büyük çoğunluğu büyükşehir belediyelerine bırakılmıştır. Belde belediyeleri ve köylerin tüzel kişiliği kaldırılarak bağlı oldukları ilçenin mahallesi haline dönüştürülmüşlerdir. Bu mahalleye dönüştürülen yerleşim alanlarına hizmetlerin çoğu bağlı olduğu ilçe belediyesi tarafından ve bazı önemli hizmetler de büyükşsehir belediyesi tarafından sunulacaktır. Büyükşehir belediyelerinin ve ilçe belediyelerinin hizmet alanları il mülki sınırlarına kadar genişlemiştir. Bu kapsamda büyükşsehir belediyelerine kırsal alanlarda hizmet sunma görevi de verildiği için büyükşehir yönetimlerinde Kırsal Hizmetler Daire Başkanlıkları kurulmuştur. Böylece kır-kent ayrımı konusunda birtakım yeni uygulamalar büyükşehir yönetimleri için getirilmiştir.

6360 sayılı Kanunun yürürlüğe girmesi ile birlikte köyler mahalleye dönüştürülerek buralar resmiyette şehir alanlarına dahil olmuşlardır. Kolluk mevzuatımıza göre şehir alanlarında asayiş ve güvenlik görevi polise verilmiştir. Türkiye'de iç güvenlik ile ilgili çalışmalara ve mevzuata baktığımızda, Ayata ve Dalkılıç'ın ( 2016: 127) da belirttiği gibi, Türkiye'de genel iç güvenliğin sağlanması, iki farklı kolluk kuvveti tarafından gerçekleştirildiği anlaşılmaktadır. Genel kolluk kuvveti olarak görev ifa eden, Emniyet ve Jandarma Teşkilatının görev ve sorumlulukları, günümüz kanunlarında, görev yeri esasına göre tasnif edilmiştir. Emniyet Teşkilatı, (Polis) şehir merkezlerinde, Jandarma Teşkilatı (Jandarma) şehir merkezi dışında kalan alanlarda görevlerini ifa etmektedir.

Gerek Ayata ve Dalk1lıç'ın tespitlerine göre, gerek ise 2803 sayılı Jandarma Teşkilat Görev ve Yetkileri Kanunu ile 1706 sayılı Jandarma Kanunda ve yine 2559 sayılı Polis Vazife ve Salahiyetleri Kanununda belirtildiğine göre polisin görev alanı genellikle şehir bölgeleri, jandarmanın görev alanı ise şehir dışında kalan kırsal alanlardır. Ancak kolluk kuvvetlerinin görev alanı en başta mevzuatımızda böyle belirlenmiş olmasına rağmen, asayiş ve güvenlik konusunda önemli bir kanun olan 2803 sayılı Kanuna daha sonraları yapılan eklemelerle jandarma ve polisin görev alanında mülki amirlerin alacakları birtakım kararlarla polis'in olmadığı alanlarda jandarmanın görev yapabilmesine olanak sağlanmıştır. Nitekim Gözler'in eleştirisi 
de 6360 sayılı Kanunun yürürlüğe girmesi ile köylerin mahalleye dönüştürülerek şehir alanına dahil olması sonucunda mevzuata göre normalde buralarda polisin asayiş ve güvenliği sağlaması gerekmektedir. Fakat Gözler'in de iddia ettiği gibi şu anda polis teşkilatının bu alanlarda asayiş ve güvenliği sağlamaya ne elindeki teçhizat yeterlidir ne de bu alanlara yetecek kadar personele sahiptir. Bu açıdan değerlendirildiğinde 2803 say1lı Kanuna 2015 y1lından sonra ya yeni bir yasayla ya da KHK ile 2018 y1l dahil her y1l yapilan ek cümlelerle bahsedilen bu açığın giderilmeye çalışıldığı söylenebilir. Sonuç olarak nitel araştırma bulgularından da anlaşılacağı gibi, jandarma 30 büyükşehir belediyesi kırsal alanlarında eskiden mevcut olan kırsal alanlardaki güvenlik ve asayiş görevine devam etmektedir ve şu anki polis teşkilatının yapısında hükümetler bir değişiklik yapmadığı sürece kırsal alanlarda asayiş ve güvenlik böyle yürütülecektir denebilir.

\section{KAYNAKÇA}

ARIKBOĞA, E. (2015), "Türkiye'de Dönüşen Büyükşehirler ve Yerel Siyaset," YEREL DEMOKRASI SORUNSALI BÜYKŞEHIR BELEDIYE MECLISLERI YAPISI VE ISŞLEYŞ̧I (49-71), İstanbul Bilgi Üniversitesi Yayınları, Derleyen: Pınar Uyan Semerci, İstanbul.

AYATA, A. ve DALKILIÇ, Y. (2016), "Emniyet Ve Jandarma Teşkilatının Kurumsal Açıdan Bütünleşmesi” Akademik Bakış Dergisi Say1: 53 (124-137), İktisat ve Girişimcilik Üniversitesi, Türk Dünyası Kırgız - Türk Sosyal Bilimler Enstitüsü, Celalabat KIRGIZISTAN, Erişim T: 10.03.2019, http://www.akademikbakis.org.

BARBAK, A. (2017), “6360 Sayılı Kanun Ve İllerde İç Güvenlik Yönetiminde Değişim”, Mehmet Akif Ersoy Üniversitesi Sosyal Bilimler Enstitüsü Dergisi, Cilt.9 Say1.19 (231-253).

ÇELIKYAY, H. (2014), DEĞISSSEN KENT YÖNETIMİ VE 6360 SAYILI BÜYÜKŞEHIR YASASI, SETA | SIYASET, EKONOMİ VE TOPLUM ARAŞTIRMALARI VAKFI, Temmuz 2014 say1: 101, İstanbul.

DOĞAN, F. (2010), "Polis Ve Jandarma Teşkilatları Açısından İç Güvenlik Yönetimi, Sorunları Ve Değişimi”, Yüksek Lisans Tezi, T.C. Ankara Üniversitesi Sosyal Bilimler Enstitüsü Kamu Yönetimi Ve Siyaset Bilimi Anabilim Dalı, Ankara.

GÜL, H. ve BATMAN, S. (2013), "Dünya Ve Türkiye Örneklerinde Metropoliten Alan Yönetim Modelleri Ve 6360 Say1lı Yasa", Yerel Politikalar Dergisi, S.3, (7-47).

GÖZLER, K. (2013), “6360 Sayılı Kanun Hakkında Eleştiriler: Yirmi Dokuz İlde İl Özel İdareleri ve Köylerin Kaldırılması ve İlçe Belediyelerinin Büyükşehir İlçe Belediyesi Hâline Dönüştürülmesi Anayasamıza Uygun mudur?”, Legal Hukuk Dergisi, Cilt 11, Sayı 122, (3782).

ÖZGÜR, H. ve YAVUZÇEHRE, P.S. (2016), "Türkiye'nin Büyükşehir Belediyesi Sistemi:19822015”, Çankırı Karatekin Üniversitesi Sosyal Bilimler Enstitüsü Dergisi, 7(1), (903-926).

YENİGÜL, S.B. (2016), "Büyükşehirlerde Tarımsal Alanların Korunmasında Kentsel Tarım ve Yerel Yönetimlerin Rolü”, MEGARON 2016;11(2), (291-299).

ZENGIN, O. (2014), "Büyükşehir Belediyesi Sisteminin Dönüşümü: Son On Y1lın Değerlendirilmesi," Ankara Barosu Dergisi, S.2, (91-116).

ZENGIN, O. (2015), “ Büyükşehir Belediyesi Reformu ve Kırsal Alana Etkisi”, s.7, http://21inciyuzyilicinplanlama.org/wp-content/uploads/2016/08/Ozan-Zengin-

14.11.2015.pdf e.t. 03.03.2019.

\section{9 sayılı POLİS VAZIFE VE SALÂHIYET KANUNU}

(www.mevzuat.gov.tr, e.t. 22.03.2019).

2803 sayılı Jandarma Teşkilat Görev ve Yetkileri Kanunu (www. Mevzuat.gov.tr, e.t.22.03.2019).

6638 sayılı Polis Vazife ve Salâhiyet Kanunu, Jandarma Teşkilat, Görev ve Yetkileri Kanunu İle Bazı Kanunlarda Değişiklik Yapılmasına Dair (https://www.tbmm.gov.tr/kanunlar/k6638.html, e.t. 22.03.2019).

1706 sayıl1 Jandarma Kanunu, (http://www.resmigazete.gov.tr/arsiv/1526.pdf, e.t. 22.03.2019). 
(http://www.mevzuat.gov.tr/MevzuatMetin/1.3.3201.pdf, e.t. 22.03.2019). 